\title{
PERAN SISTEM AKUNTANSI INSTANSI BERBASIS AKRUAL DALAM MENINGKATKAN KUALITAS LAPORAN KEUANGAN
}

\author{
Ida Najati ${ }^{1}$ \\ Endar Pituringsih ${ }^{2}$ \\ Animah $^{3}$ \\ ${ }^{1,2,3}$ Fakultas Ekonomi Universitas Mataram, Nusa Tenggara Barat, Indonesia \\ email: animahmtr@gmail.com
}

\begin{abstract}
ABSTRAK
Penelitian ini bertujuan untuk menguji secara empiris pengaruh penggunaan Sistem Akuntansi Instansi Berbasis Akrual (SAIBA) dalam kaitannya implementasi akuntansi akrual dan kualitas Laporan Keuangan Kementerian/ Lembaga (LKKL). Populasi dalam penelitian ini adalah 464 operator aplikasi SAIBA yang digunakan di wilayah KPPN Makasar I dan II. Sampel ditentukan berdasarkan rumus Slovin dan cluster sampling, dan diperoleh 82 responden yang terdiri dari 33 responden di wilayah KPPN Makasar I dan 49 responden di KPPN Makasar II. Analisis data menggunakan PLS dengan second order confirmatory factor analysis. Hasil penelitian menunjukan bahwa implementasi akuntansi berbasis akrual berpengaruh signifikan terhadap penggunaan aplikasi SAIBA dan penggunaan aplikasi SAIBA berpengaruh signifikan terhadap LKKL. Hasil penelitian juga menunjukan bahwa implementasi akuntansi akrual berpengaruh signifikan terhadap LKKL. Semakin maksimal implementor menggunakan aplikasi SAIBA dalam perencanaan laporan akuntansi keuangan berbasis akrual, maka semakin dapat meningkatkan kualitas atas LKKL.
\end{abstract}

Kata kunci: Kementerian, akrual, SAIBA

\section{THE ROLES OF ACCRUAL ACCOUNTING SYSTEM IN IMPROVING THE QUALITY OF INSTITUTIONAL FINANCIAL ACCOUNTING REPORT}

\section{ABSTRACT}

\begin{abstract}
The study objectives are to empirically examine the influence of usage of SAIBA as relationship between accrual accounting implementation and quality of Ministry/Board financial accounting report (LKKL). The research population are 464 SAIBA operators of KPPN Makassar I and II stakeholders. Samples quantity which determined by Slovin technique and cluster sampling are 82 respondents, consist of 33 respondents on KPPN Makassar I and 49 respondents on KPPN Makassar II. Data analysis tool used is $P L S$ with second order confirmatory factor analysis. The finding shows that accrual accounting implementation has a significant effect on usage of SAIBA and the usage of SAIBA has a significant effect to quality of Ministry/Board financial accounting report (LKKL). The other finding indicated that accrual accounting implementation has significant effect on quality of Ministry/Board financial accounting report $(L K K L)$. The maximum implementor use SAIBA in the preparation of accrual-based financial accounting report, the more it will improve the quality of Ministry/Board financial accounting report (LKKL).
\end{abstract}

Keywords : Ministry, accrual, SAIBA

DOI: https://doi.org/10.24843/JIAB.2017.v12.i01.p04

\section{PENDAHULUAN}

Laporan Keuangan Kementerian/Lembaga (LKKL) yang disusun oleh Menteri/Pimpinan Lembaga merupakan salah satu bentuk akuntabilitas dalam mewujudkan good governance. LKKL yang disusun pada tahun 2005 sebagai bentuk pertanggungjawaban APBN tahun 2004, merupakan LKKL pertama kali yang dihasilkan menteri/ pimpinan lembaga. Penyusunan LKKL berpedoman pada Standar Akuntansi Pemerintahan (SAP).

LKKL tahun 2004-2014 dihasilkan dari Sistem Akuntansi Keuangan Pengguna Anggaran (SAKPA) dengan basis Cash Towards Accrual (CTA). Sejalan dengan amanat reformasi keuangan Negara serta sesuai dengan Peraturan Pemerintah Nomor 71 Tahun 2010 tentang SAP, maka sejak tahun 2015 penyusunan LKKL disusun menggunakan akuntansi berbasis akrual. Akuntansi berbasis akrual mengakui pendapatan dan belanja (biaya) bukan pada saat kas diterima atau dibayarkan, tetapi diakui atau dicatat pada saat transaksi terjadi.

Perubahan basis akuntansi dari CTA ke basis akrual disebabkan karena ada beberapa hal yang 
tidak bisa dipenuhi oleh akuntansi berbasis CTA. Laporan keuangan berbasis CTA belum memperlihatkan kinerja pemerintah secara keseluruhan, tidak menyajikan informasi keuangan yang sesungguhnya, dan kurang memberikan rekam jejak atas perubahan nilai ekuitas pemerintah (Amriani, 2014). Akan tetapi, informasi akuntansi berbasis akrual hanya dapat disajikan secara periodik (semester dan tahunan) menyulitkan penyediaan informasi keuangan secara insidentil sebagai dasar pengambilan keputusan.

Sesuai dengan decision usefulness theory, informasi yang terkandung dalam laporan keuangan harus memberikan manfaat baik bagi penyusun maupun pengguna laporan keuangan sebagai dasar pengambilan keputusan. Laporan keuangan yang dihasilkan dari penerapan akuntansi berbasis akrual dimaksudkan untuk memberikan informasi yang lebih komprehensif dan lebih baik bagi para pemangku kepentingan dibandingkan dengan basis kas menuju akrual (CTA). Hal ini sejalan dengan salah satu prinsip akuntansi yaitu pengungkapan paripurna atau full disclosure (PPAKP, 2014).

Simanjuntak (2010) menyatakan bahwa kompleksitas implementasi akuntansi berbasis akrual memerlukan sistem akuntansi dan IT based system yang lebih rumit. Dalam rangka penerapan basis akuntansi akrual di Pemerintah Pusat, Direktorat Jenderal Perbendaharaan Kementerian Keuangan sebagai barisan terdepan dalam implementasi akuntansi berbasis akrual telah mengembangkan aplikasi akuntansi yang selama ini telah digunakan dalam basis kas menuju akrual (cash toward accrual) yaitu aplikasi Sistem Akuntansi Keuangan Pengguna Anggaran (SAKPA), menjadi Sistem Akuntansi Instansi Berbasis Akrual (SAIBA). Aplikasi SAIBA merupakan sistem akuntansi keuangan yang digunakan dalam penyusunan Laporan Keuangan Kementerian/Lembaga (LKKL) berbasis akrual.

Mengingat sejak 2005 sampai 2014 aplikasi SAKPA telah digunakan oleh Kementerian Negara/ Lembaga dalam menyusun laporan keuangannya, sehingga dapat dikatakan semua satuan kerja telah familiar dengan aplikasi tersebut. Pengembangan SAI menjadi SAIBA merupakan terobosan aplikasi akuntansi berbasis akrual yang diharapkan memenuhi kebutuhan informasi laporan keuangan yang disyaratkan oleh SAP. Aplikasi SAKPA harus dimodifikasi sehingga dapat menghasilkan laporan keuangan berbasis akrual berupa Laporan Realisasi Anggaran (LRA), Laporan Operasional (LO), Laporan Perubahan Ekuitas (LPE), dan Neraca. SAIBA dibangun dengan harapan operator tidak mengalami kesulitan dalam menjalankan aplikasi SAIBA karena SAUBA adalah pengembangan dari SAKPA. Aplikasi ini mulai digunakan untuk penyusunan laporan keuangan bulan Januari 2015. Satuan kerja yang sudah menggunakan aplikasi SAIBA sejak bulan Januari 2015 antara lain adalah satuan kerja mitra kerja Kantor Pelayanan Perbendaharaan Negara Makassar I dan II (KPPN Makassar I dan II).

Penelitian ini termotivasi dari penelitian Abas (2015), Asterini (2015), Ofoegbu dan Grace (2014) serta Christanti (2013). Perbedaan penelitian ini dengan penelitian sebelumnya terletak pada variabel penelitian yang dibangun. Orisinalitas penelitian ini terletak pada penggunaan variabel penggunaan aplikasi SAIBA sebagai variable intervening.

Berdasarkan latar belakang di atas dapat diketahui bahwa implementasi akuntansi berbasis akrual merupakan hal yang baru diterapkan pada Pemerintah Pusat, yang memiliki peran penting dalam peningkatan kualitas LKKL yang secara tidak langsung akan mempengaruhi kredibilitas Pemerintah Pusat, baik di dalam negeri maupun di tingkat internasional. Sehubungan dengan hal tersebut, maka peneliti tertarik untuk meneliti pengaruh implementasi akuntansi berbasis akrual terhadap kualitas laporan keuangan Kementerian/ Lembaga dengan penggunaan aplikasi SAIBA sebagai variabel intervening.

Teori kegunaan keputusan (decision usefulness) merupakan suatu pendekatan terhadap laporan keuangan yang memiliki pandangan apabila laporan keuangan tidak bisa disiapkan secara teoritis berkonsep wajar, paling tidak penyusunan laporan keuangan historis harus lebih bermanfaat (Scott, 2003). Penyajian informasi laporan keuangan yang sesuai dengan manfaat atau kebutuhan tertentu akan memperbaiki proses pengambilan keputusan.

Technology Acceptance Model (TAM) merupakan model penerimaan sistem informasi yang dikemukakan oleh Davispada tahun1986.TAM menjelaskan bahwa ada dua faktor atau keyakinan yang menyebabkan penggunaan teknologi, yaitu kegunaan persepsian (perceived usefulness) dan kemudahan penggunaan persepsian (perceived ease of use)penggunaan persepsian (perceived ease of use). Kegunaan persepsian didefinisikan sejauh mana pandangan subjektif pengguna bahwa menggunakan sistem aplikasi tertentu akan meningkatkan kinerja pekerjaannya. Kemudahan penggunaan persepsian (perceived ease of use) penggunaan persepsian merujuk pada sejauh mana pengguna percaya bahwa menggunakan suatu teknologi akan bebas dari suatu usaha (Davis, et al. 1989). 
Indikator kegunaan persepsian(perceived usefulness) meliputi (a) work more quickly, (b) improve job performance, (c) increase productivity, (d) enhance effectivenesss, (e) useful, dan (f) makes job easier. Indikator kemudahan penggunaan persepsian (perceived ease of use) penggunaan persepsian (perceived ease of use) meliputi: (a) easy to learn, (b) controllable, (c) clear and understandable, (d) flexible, (e) easy to become skillfull, dan (f) easy to use (Davis et. al., 1989).

Pengertian karakteristik kualitatif dalam Peraturan Pemerintah Nomor 71 Tahun 2010 adalah ukuran-ukuran normatif yang perlu diwujudkan dalam informasi akuntansi sehingga dapat memenuhi tujuannya. Laporan keuangan harus memiliki karakteristik kualitatif yang memadai sehingga laporan keuangan bermanfaat bagi pengambil keputusan. Berdasarkan PP No 71 Tahun 2010, terdapat empat karakteristik kualitatif yang harus dipenuhi dalam laporan keuangan, yaitu relevan, andal, dapat dipahami, dan dapat dibandingkan. Informasi keuangan yang relevan mampu membuat perbedaan dalam keputusan yang dibuat oleh pengguna (Lam dan Lau, 2014). Menurut PP 71 tahun 2010, informasi yang relevan harus memiliki manfaat prediksi, manfaat umpan balik, tepat waktu dan lengkap. Suatu informasi dalam laporan keuangan dikatakan andal atau dapat dipercaya jika disajikan secara jujur, dapat diverifikasi dan netral (Belkaoui dan Riahi, 2000). Dapat dibandingkan artinya pengguna dapat mengevaluasi informasi keuangan suatu entitas dengan membandingkan laporan keuangan dari waktu ke waktu dan antar entitas (Lam dan Lau, 2014). Dapat dipahami artinya suatu informasi menjadi bermanfaat apabila dapat dipahami oleh para penggunanya. Laporan keuangan harus disajikan dengan bahasa yang sederhana, singkat, formal dan mudah dipahami (Purba, 2010).

Pengertian akuntansi berbasis akrual dalam PP No 71 Tahun 2010 adalah basis akuntansi dimana transaksi ekonomi atau peristiwa akuntansi diakui, dicatat dan disajikan dalam laporan keuangan tersebut pada saat terjadinya transaksi, tanpa memperhatikan waktu kas atau setara kas diterima atau dibayarkan. Wijajarso (2011) Tujuan penggunaan basis akrual menurut Heather Thompson, Project Manager dari Transition from Cash to Accrual Accounting Project, Public Expenditure Management, pemerintah Barbados, adalah untuk meningkatkan efisiensi dan efektivitas sistem keuangan (penganggaran, akuntansi dan pelaporan); untuk meningkatkan pengendalian fiskal, manajemen aset dan budaya sektor publik; untuk meningkatkan akuntabilitas dalam program penyediaan barang dan jasa oleh pemerintah; menyediakan informasi yang lebih lengkap bagi pemerintah untuk pengambilan keputusan; untuk mereformasi sistem anggaran belanja (apropriasi) dan untuk mencapai transparansi yang lebih luas atas biaya pelayanan yang dilakukan oleh pemerintah.

Komponen laporan keuangan sesuai dengan Peraturan Pemerintah Nomor 71 Tahun 2010 adalah Laporan Realisasi Anggaran (LRA), Laporan Perubahan Saldo Anggaran Lebih, Neraca, Laporan Arus Kas (LAK), Laporan Operasional (LO), Laporan Perubahan Ekuitas (LPE), dan Catatan atas Laporan Keuangan. Uraian dari masing-masing komponen laporan keuangan adalah laporan Realisasi Anggaran (LRA), menyajikan sumber, alokasi dan pemakaian sumber daya keuangan; laporan Perubahan Saldo Anggaran Lebih (Laporan Perubahan SAL), menyajikan informasi kenaikan atau penurunan SAL tahun pelaporan dibandingkan dengan tahun sebelumnya; neraca, merupakan laporan keuangan yang menggambarkan posisi keuangan entitas pelaporan mengenai aset, kewajiban, dan ekuitas pada tanggal tertentu; laporan Arus Kas (LAK), menyajikan informasi penerimaan dan pengeluaran kas selama periode tertentu berdasarkan aktivitas operasi, investasi, pendanaan, dan transitoris; laporan Operasional (LO), menyajikan seluruh kegiatan operasional keuangan entitas pelaporan yang tercermin dalam pendapatan-LO, beban, dan surplus/ defisit operasional yang penyajiannya disandingkan dengan periode sebelumnya; Laporan Perubahan Ekuitas (LPE), menyajikan informasi kenaikan atau penurunan ekuitas tahun pelaporan dibandingkan dengan tahun sebelumnya dan Catatan atas Laporan Keuangan (CaLK), berisi penjelasan atau daftar terinci atau analisis atas nilai suatu pos yang disajikan dalam LRA, Laporan Perubahan SAL, Neraca, LO, LAK, dan LPE. CaLK juga berisi pengungkapan lainnya yang diperlukan.

Direktorat Jenderal Perbendaharaan mengembangkan dan memodifikasi aplikasi yang selama ini telah digunakan dalam penyusunan LKKL, yaitu aplikasi SAKPA menjadi aplikasi SAIBA. Aplikasi SAIBA merupakan software yang dirancang sebagai sistem akuntansi keuangan yang digunakan dalam penyusunan laporan keuangan berbasis akrual. Aplikasi SAIBA merupakan terobosan yang diharapkan dapat memenuhi kebutuhan informasi laporan keuangan sesuai SAP.

Proses pengoperasian aplikasi SAIBA sama dengan aplikasi SAKPA yaitu dimulai dari perekaman dokumen, posting buku besar, dan penyusunan laporan 
keuangan. Perbedaan aplikasi SAIBA dan SAKPA terletak pada perekaman migrasi saldo awal neraca, perekaman transaksi DIPA dan Revisi DIPA, serta perekaman transaksi periode berjalan. Perbedaan lain adalah operator aplikasi SAIBA perlu melakukan penyesuaian sebelum menyusun laporan keuangan untuk menentukan jumlah yang sebenarnya dari setiap akun sesuai dengan basis akrual.

Kebijakan akuntansi berbasis akrual merupakan salah satu bentuk kebijakan yang dihasilkan dari reformasi pengelolaan keuangan negara yang merupakan upaya untuk meningkatkan kualitas LKKL. Implementasi akuntansi berbasis akrual memberikan tantangan bagi pemerintah untuk merancang sebuah sistem informasi akuntansi berbasis akrual. Aplikasi SAIBA merupakan SIA yang digunakan untuk membantu penyusunan LKKL. Secara tidak langsung penggunaan aplikasi SAIBA akan memiliki peran dalam implementasi akuntansi berbasis akrual untuk meningkatkan kualitas LKKL.

Berdasarkan latar belakang dan rumusan masalah maka pertanyaan yang akan dijawab dalam penelitian ini adalah apakah implementasi akuntansi berbasis akrual mempengaruhi kualitas LKKL, apakah implementasi akuntansi berbasis akrual mempengaruhi penggunaan aplikasi SAIBA, dan apakah penggunaan aplikasi SAIBA mempengaruhi kualitas LKKL. Hubungan antar variabel penelitian dapat diilustrasikan pada Gambar 1.

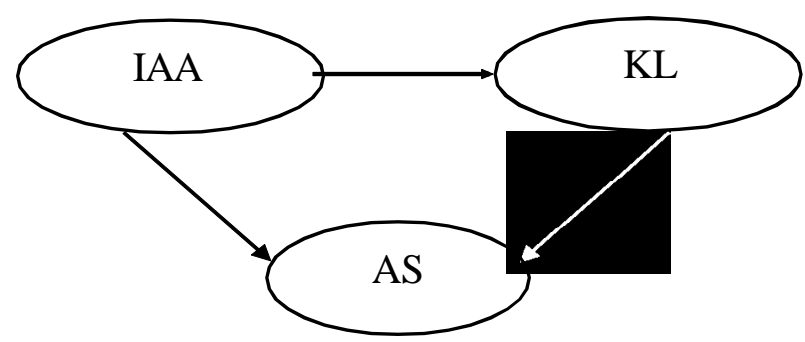

Gambar 1. Model Penelitian

Sumber: Data diolah, 2015

Decision usefulness theory menyatakan bahwa informasi yang terkandung dalam laporan keuangan harus bermanfaat bagi penyusun maupun penggunanya. Seseuai dengan karakteristikkualitatif yang dinyatakan dalam PP No 71 Tahun 2010, laporan keuangan harus relevan, andal, dapat dibandingkan, dan dapat dipahami untuk dapat menjadi laporan keuangan bermanfaat bagi pengambil keputusan.

Pemerintah pusat berupaya menyajikan informasi yang lebih lengkap dalam laporan keuangan dengan menggunakan basis akrual sebagaimana diamanatkan dalam Undang-undang Keuangan Negara (UUKN). Hal tersebut juga sesuai dengan pernyataan Heather Thompson, Project Manager dari Transition from Cash to Accrual Accounting Project, Public Expenditure Management, pemerintah Barbados, yang menyatakan bahwa salah satu tujuan penerapan basis akrual adalah menyediakan informasi yang lebih lengkap bagi pemerintah untuk pembuatan keputusan (Widjajarso, 2011).

Implementasi akuntansi berbasis akrual dimulai awal tahun 2015 mengharuskan pemerintah untuk mengembangkan sistem informasi akuntansi yang mampu mengakomodir kompleksitas akuntansi berbasis akrual (Simanjuntak, 2005). Sistem informasi akuntansi yang telah dipersiapkan oleh pemerintah adalah aplikasi SAIBA.

Technology Acceptance Model yang dikembangkan Davis (1989) menyatakan bahwa faktor yang mempengaruhi penerimaan suatu sistem, yaitu kegunaan persepsian(perceived usefulness) dan kemudahan penggunaan persepsian (perceived ease of use) penggunaan persepsian (perceived ease of use). Kegunaan persepsian TI dapat diketahui dari kepercayaan pengguna TI bahwa penggunaan TI tersebut memberikan kontribusi positif bagi penggunanya (Nasution 2004). Kemudahan penggunaan persepsian (perceived ease of use) penggunaan persepsian sebagai suatu tingkatan dimana seseorang percaya bahwa komputer dapat dengan mudah dipahami (Davis et. al., 1989). Hal yang sama juga mempengaruhi penerimaan dan niatpenggunaan aplikasi SAIBA pada Kementerian/ Lembaga selaku agen pelaksana. Dukungan terhadap implementasi akuntansi berbasis akrual akan mendorong implementor untuk menerima/ menggunakan aplikasi SAIBA.

Berdasarkan kajian teoritis, dapat disimpulkan bahwa implementasi akuntansi berbasis akrual merupakan variabel yang mempengaruhi penggunaan aplikasi SAIBA. Dengan demikian, hipotesis penelitian ini adalah sebagai berikut.

$\mathrm{H}_{1}$ : Implementasi akuntansi berbasis akrual berpengaruh pada penggunaan aplikasi sistem akuntansi instansi berbasis akrual.

Menurut Davis, at. al.,(1989) dalam TAM, reaksi dan persepsi pengguna TI akan mempengaruhi sikapnya dalam penerimaan penggunaan TI. Faktor yang mempengaruhi sikap pengguna adalah persepsi pengguna dan kemudahan penggunaan persepsian (perceived ease of use) penggunaan TI sebagai suatu yang mendorong orang untuk menerima penggunaan TI. 
Penggunaan kemajuan TI juga memberi dampak pada penyajian laporan keuangan dan telah mempengaruhi penyaji laporan keuangan untuk menyediakan suatu sistem informasi akuntansi (SIA) yang terkomputerisasi. Jika perusahaan tidak memiliki SIA yang baik, maka perusahaan tidak akan mampu menyediakan informasi yang memenuhi sayarat kualitatif informasi untuk para pembuat keputusan (McLeod dan Schell, 2001).

Pemerintah Pusat sebagai penyaji laporan keuangan juga telah merancang aplikasi SAIBA yang memungkinkan penyusun laporan keuangan menyelesaikan LKKL berbasis akrual dengan lebih mudah dan cepat serta meningkatkan tingkat akurasi data dan ketepatan informasi yang disajikan. Penggunaan aplikasi SAIBA diharapkan dapat menghasilkan output berupa laporan keuangan yang lebihber kualitas.

Abas (2015) menduga bahwa penggunaan teknologi informasi berpengaruh terhadap kualitas laporan keuangan. Pemanfaatan teknologi informasi juga akan mengurangi kesalahan yang terjadi dan meningkatkan kecepatan dalam pemrosesan informasi. Kemajuan teknologi informasi yang pesat serta potensi pemanfaatan secara luas maka dapat membuka peluang bagi berbagai pihak untuk mengakses, mengelola dan mendayagunakan informasi keuangan secara cepat dan akurat (Asterini 2015).

Berdasarkan kajian teoritis, dapat disimpulkan bahwa penggunaan aplikasi SAIBA merupakan variabel yang mempengaruhi kualitas LKKL. Dengan demikian, hipotesis penelitian ini adalah:

$\mathrm{H}_{2}$ : Penggunaan aplikasi sistem akuntansi instansi berbasis akrual berpengaruh pada kualitas laporan keuangan kementerian/lembaga.

Decision usefulness theory menyatakan bahwa informasi yang terkandung dalam laporan keuangan harus bermanfaat bagi para pengguna sebagai dasar pengambilan keputusan. Laporan keuangan yang bermanfaat dapat dikatakan sebagai laporan keuangan yang berkualitas bila memenuhi syarat kualitatif informasi keuangan, yaitu relevan, andal, mudah dipahami dan keterbandingan. Pergeseran dari akuntansi berbasis kas menjadi akuntansi berbasis akrual untuk mendapatkan informasi keuangan yang bermanfaat (Simanjuntak,2005).

Penggunaan basis akrual dalam pelaporan keuangan pemerintah, merupakan upaya untuk mendukung perbaikan kualitas laporan keuangan (Syaiful 2014:44). Laporan keuangan yang disusun dengan basis akrual dapat menganalisis transaksi secara layak dan lebih dapat diandalkan. Selain itu basis akrual dapat merepresentasikan reliabilitas, relevansi dan komparabilitas informasi yang diungkapkan dalam laporan, sehingga dapat dipastikan bahwa informasi telah disajikan secara jujur (Sari dan Putra, 2012).

Tujuan penerapan basis akrual adalah untuk meningkatkan kualitas pengambilan keputusan pemerintah (Widjajarso, 2011). Kajian dari Deloitte menyebutkan bahwa akuntansi berbasis akrual secara signifikan memberikan kontribusi untuk meningkatkan kualitas pengambilan keputusan untuk efisiensi dan efektivitas pengeluaran publik melalui informasi keuangan yang akurat dan transparan (Simanjuntak, 2005).

Penerapan akuntansi berbasis akrual merupakan hal yang baru dalam penyusunan LKKL, namun hal tersebut diyakini memiliki kemampuan untuk meningkatkan kualitas laporan keuangan (Christanti 2013). Informasi yang berkualitas tinggi hanya dapat dibuat melalui adopsi dan penerapan akuntansi berbasis akrual di sektor publik (Ofoegbu dan Grace 2014).

Berdasarkan kajian teoritis, dapat disimpulkan bahwa implementasi akuntansi berbasis akrual merupakan variabel yang mempengaruhi kualitas LKKL. Dengan demikian, hipotesis penelitian ini adalah:

$\mathrm{H}_{3}$ : Implementasi akuntansi berbasis akrual berpengaruh terhadap kualitas laporan keuangan kementerian/lembaga

\section{METODE PENELITIAN}

Jenis penelitian yang digunakan dalam penelitian ini adalah penelitian asosiatif. Hubungan yang digunakan dalam penelitian ini adalah hubungan kausal (sebab-akibat). Pada hipotesis sebab-akibat ada implikasi bahwa adanya atau berubahnya satu variabel menyebabkan atau berpengaruh pada variabel yang lain (Cooper dan Emory ,1997).

Populasi penelitian adalah operator aplikasi SAIBA pada satuan kerja KPPN Makasar I dan II, berjumlah 464 orang. Jumlah sampel yang ditentukan dengan teknik Slovin dan cluster sampling adalah 82 responden yang terdiri atas 33 operator aplikasi SAIBA KPPN pada satuan kerja Makassar I dan 49 operator aplikasi SAIBA pada satuan kerja KPPN Makassar II.

Implementasi akuntansi berbasis akrual merupakan penyusunan laporan keuangan berbasis akrual dengan mempedomani lampiran I PP No 71 Tahun 2010 tentang SAP. Dimensi yang digunakan adalah (a) dimensi pengakuan pendapatan yang diukur 
diukur berdasarkan pengakuan pendapatan pada Laporan Operasional dan pengakuan pendapatan pada Laporan Realisasi Anggaran, (b) dimensi pengakuan beban dan belanja yang diukur berdasarkan pengakuan beban dan pengakuan belanja, (c) dimensi akuntansi persediaan yang diukur dengan pengakuan, pengukuran, dan pengungkapan persediaan, (d) dimensi akuntansi aset tetap yang diukur dengan pengakuan, pengukuran dan pengungkapan persediaan serta depresiasi, (e) dimensi akuntansi kewajiban yang ini diukur dengan pengakuan, pengukuran dan pengungkapan kewajiban, (f) dimensi laporan operasional yang diukur dengan penyajian laporan operasional, dan (g) dimensi laporan perubahan ekuitas yang diukur dengan penyajian laporan perubahan ekuitas. Kuisioner terdiri atas 10 item pernyataan atau pertanyaan diadaptasi dari kuisioner penelitian Switriansyah (2015).

Aplikasi SAIBA merupakan sistem informasi akuntansi yang digunakan dalam penyusunan laporan keuangan berbasis akrual. Dimensi yang digunakan adalah dimensi dalam technology acceptance model yang dikemukakan oleh Davis, et al. (1989) yaitu : (a) dimensi perceived of use yang diukur dari sisi work more quickly, improve job performance, increase productivity, enhance effectiveness, useful, and makes job easier, dan (b) dimensi perceived of ease yang diukur dari sisi easy to learn, controllable, clear and understandable, flexible, easy to become skillfull, and easy to use. Kuisioner terdiri atas 12 item pernyataan atau pertanyaan diadaptasi dari penelitian Muharor(2015).

Kualitas LKKL merupakan unsur-unsur yang harus dipenuhi dalam LKKL agar dapat bermanfaat dalam pengambilan keputusan. Dimensi yang digunakan untuk variabel implementasi akuntansi berbasis akrual adalah karakteristik kualitatif laporan keuangan sesuai dengan PP No 71 Tahun 2010 yaitu (a) dimensi relevan yang diukur dengan melihat manfaat umpan balik, manfaat prediktif, tepat waktu dan lengkap, (b) dimensi andal yang diukur dengan penyajian jujur, netralitas dan dapat diverifikasi, (c) dimensi mudah dibandingkan yang diukur dengan perbandingan dengan periode sebelumnya dan perbandingan dengan satuan kerja lain, dan (d) dimensi mudah dipahami yang diukur dengan informasi yang rinci, informasi sesuai kebutuhan dan pemahaman informasi. Kuisioner penelitian terdiri atas 13 item pernyataan atau pertanyaan diadaptasi dari penelitian Roni (2015).

Instrumen dalam penelitian ini adalah kuisioner dengan skala likert untuk mengukur sikap responden terhadap pernyataan atau pertanyaan yang diajukan baik dalam bentuk pernyataan atau pertanyaan positif maupun negatif. Pernyataan atau pertanyaan negatif digunakan agar responden membaca dengan cermat setiap pernyataan yang ada (Widoyoko 2014). Skala likert yang digunakan adalah skala likert empat. Alasan penggunaan skala likert empat adalah tidak memberi kesempatan bagi responden untuk bersikap netral dan memaksa responden untuk menentukan sikap terhadap fenomena sosial yang ditanyakan atau dinyatakan dalam instrument (Widoyoko2014:105).

Analisis data yang digunakan dalam penelitian ini adalah second order confirmatory factor analysis dengan bantuan program SmartPLS versi 2.0. Gambar model struktural dan pengukuran dengan PLS disajikan pada lampiran. Sedangkan persamaan model struktural penelitian ini adalah:

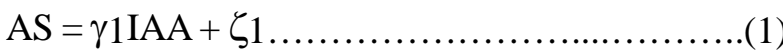

$\mathrm{KL}=\beta 1 \mathrm{AS}+\gamma 2 \mathrm{IAA}+\zeta 2 \ldots \ldots \ldots \ldots \ldots \ldots \ldots . .(2)$

Keterangan:

IAA = implementasi akuntansi berbasis akrual

AS = penggunaan aplikasiSAIBA

$\mathrm{KL} \quad=$ kualitasLKKL

$\gamma($ Gama $)=$ koefisien pengaruh variabel eksogen terhadap variabel laten endogen

$\beta$ (Beta) $=$ koefisien pengaruh variabel endogen terhadap variabel latenendogen

$\zeta$ (Zeta) = galat model struktural

Menurut Baron dan Kenny (1986) suatu variabel disebut variabel intervening jika variabel tersebut ikut mempengaruhi hubungan antara variabel eksogen dan variabel endogen. Pengujian hipotesis mediasi dilakukan dengan uji Sobel dengan cara menguji kekuatan pengaruh tidak langsung variabel eksogen (X) ke variabel endogen (Y) melalui variabel intervening (M). Sab dihitung dengan rumus dibawah ini (Ghozali, 2009 dalam Nengsy et al. 2013):

$S a b=\sqrt{ } \mathbf{b}^{2} \mathrm{Sa}^{2}+\mathrm{a}^{2} \mathrm{Sb}^{2}+\mathrm{Sa}^{2} \mathrm{Sb}^{2}$.

Untuk menguji signifikansi pengaruh tidak langsung, maka kita perlu menghitung nilai $t$ dari koefisien abdengan rumus sebagai berikut:

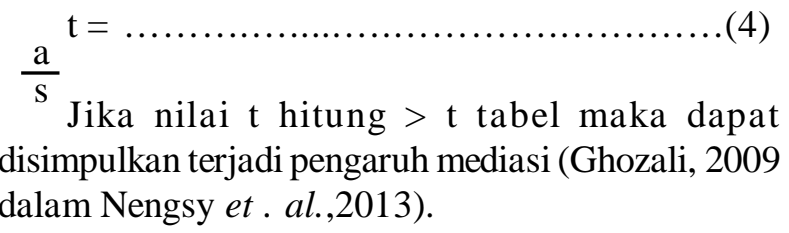




\section{HASIL DAN PEMBAHASAN}

Tingkat pengembalian kuisioner mencapai 97,56\% atau sebanyak 80 dari 82 kuisioner yang disebar. Kuisioner yang dapat diolah adalah 73 kuisioner $(89,02 \%)$. Sebanyak tujuh kuisioner tidak dapat diolah karena beberapa pernyataan tidak dijawab (kosong).

Evaluasi outer model dilakukan untuk menilai validitas dan reliabilitas model. Outer model dengan indikator refleksif dievaluasi melalui convergent validity, discriminant validity dan composite reliability untuk blok indikatornya (Ghozali dan Latan, 2012). Hasil evaluasi outer model tahap I untuk first order adalah 5 indikator dinyatakan tidak memenuhi convergent validity karena memiliki nilai loading factor <0,6 dan 29 indikator dinyatakan memenuhi convergent validity karena memiliki nilai loading factor $>0,6$. Indikator yang tidak memenuhi convergent validity adalah indikator AS.PU3 $(0,480)$, AS.PU.5 (0,457),KL.RL3 (0,588), KL.AD1 $(0,585)$ dan KL.DB2 $(0,442)$.

Ketujuh indikator yang tidak memenuhi convergent validity tersebut didrop dari model, dan kemudian dilakukan pengujian ulang. Hasil evaluasi outer model tahap II menunjukkan bahwa semua loading factor memiliki nilai > 0,6 sehingga memenuhi convergent reliability. Selain memenuhi nilai loading factor yang dipersyarakan, nilai AVE seluruh konstruk juga memenuhi persyaratan convergent validity yaitu $>0,5$. Disamping memenuhi persyaratan convergent validity, PLS algorithm report juga menunjukkan bahwa semua konstruk dimensi memiliki reliabilitas yang baik karena memiliki nilai composite reliability $>0,7$.

Penelitian ini menggunakan second order construct, sehingga langkah selanjutnya adalah melakukan bootstrapping untuk melihat signifikansi dalam nilai t-statistik pada tabel outer loadings. Kriterianya adalah $t$-statistic $>1,66$ (nilai alpha 10\%, two tail). Berdasarkan kalkulasi akhir PLS pada menu bootstrapping, nilai $t$-statistics pada tabel outer loadings menunjukkan bahwa nilai t-statistic $>1,66$ yang berarti bahwa semua first order signifikan atau valid.Nilai $t$ - statistics pada tabel path coefficients juga menunjukkan angka >1,66. Berdasarkan hasil tersebut dapat disimpulkan bahwa semua second order construct atau konstruk variabel dapat dibentuk oleh masing-masing first order construct.

Evaluasi inner model bertujuan untuk memprediksi hubungan antar variabel laten. Inner model dievaluasi dengan melihat nilai $R$-square untuk konstruk laten endogen dan nilai $t$ - statistics pada tabel path coefficients untuk uji signifikansi melalui menu bootstrapping. Nilai $R$-square untuk variabel penggunaan aplikasi SAIBA (AS) dapat di terangkan oleh variabel implementasi akuntansi berbasis akrual (IAA) sebesar 26,99\% (moderat), sementara 73,01\% diterangkan oleh variabel lain yang tidak diteliti. Variabel kualitas LKKL (KL) dapat diterangkan oleh variabel implementasi akuntansi berbasis akrual (IAA) dan variabel penggunaan aplikasi SAIBA (AS) sebesar 58,37\% (moderat), sedangkan sebesar 41,63 $\%$ diterangkan oleh variabel lain yang tidak diteliti. Nilai $R$-Square disajikan di lampiran Tabel 2.

Selain $R$-Square, evaluasi inner model melalui menu bootsrapping juga menghasilkan Nilai $T$ statistics yang akan digunakan untuk menguji hipotesis. Hasil penelitian menunjukkan bahwa implementasi akuntansi berbasis akrual (IAA) berpengaruh terhadap penggunaan aplikasi SAIBA (AS) dengan nilai Tstatistic sebesar 6,77, implementasi akuntansi berbasis akrual (IAA) berpengaruh terhadap kualitas LKKL (KL) dengan nilai Tstatistic sebesar 4,44, dan penggunaan aplikasi SAIBA (AS) berpengaruh terhadap kualitas LKKL (KL) dengan nilai Tstatistic sebesar 4,69. Nilai Tstatistic tersebut $>1,96$ (Ttabel) sehingga menerima $\mathrm{H}_{1}, \mathrm{H}_{2}$, dan $\mathrm{H}_{3}$. Hasil nilai $T$-statistics pada tabel path coefficients disajikan pada lampiran Tabel 3.

Sedangkan untuk menguji apakah aplikasi SAIBA menjadi variabel intervening dalam hubungan antara implementasi akuntansi berbasis akrual (IAA) dan kualitas LKKL (KL) dilakukan dengan uji Sobel (Sobel test). Besarnya pengaruh tidak langsung ini dapat dihitung dengan mengalikan koefisien $(\mathrm{a} \times \mathrm{b})=(0,517 \times 0,464)=0,239$. Besarnya standard error tidak langsung variabel implementasi akuntansi berbasis akrual terhadap kualitas LKKL (KL) merupakan perkalian dari pengaruh variabel implementasi akuntansi berbasis akrual terhadap penggunaan aplikasi SAIBA, dengan variabel penggunaan aplikasi SAIBA terhadap variabel kualitas LKKL. Hasil perhitungan diperoleh sab0,0618. Nilai T-statistics $(3,880)>T$-table $(1,66)$ dengan signifikansi level 10\% (two tailed), menunjukkan bahwa implementasi akuntansi berbasis akrual berpengaruh signifikan terhadap kualitas LKKL (KL) dengan penggunaan aplikasi SAIBA (SA) sebagai variabel intervening.

Hasil pengujian hipotesis melalui PLS menunjukkan bahwa nilai $t$-statistics $>$ t-tabel, yaitu $6,77>1,66$. Hal ini menunjukkan bahwa implementasi akuntansi berbasis akrual berpengaruh terhadap penggunaan aplikasi SAIBA. Pemerintah pusat 
Tabel 1.

Path Analysis

\begin{tabular}{lccccc}
\hline & $\begin{array}{c}\text { Original } \\
(\mathrm{O})\end{array}$ & $\begin{array}{c}\text { Sample } \\
(\mathrm{M})\end{array}$ & $\begin{array}{c}\text { Standard } \\
(\mathrm{STDEV})\end{array}$ & $\begin{array}{c}\text { Standard } \\
(\text { STERR })\end{array}$ & $\begin{array}{c}\text { T Statistics } \\
(\mathrm{O} / \mathrm{STER})\end{array}$ \\
\hline AS -> KL & 0,464 & 0,479 & 0,098 & 0,098 & 4,694 \\
$\mathrm{IAA}->$ AS & 0,517 & 0,524 & 0,076 & 0,076 & 6,771 \\
$\mathrm{IAA}->$ KL & 0,411 & 0,404 & 0,092 & 0,092 & 4,447 \\
\hline
\end{tabular}

Sumber : Data diolah, 2015

berupaya menyajikan informasi yang lebih lengkap dalam laporan keuangan dengan menggunakan basis akrual, sebagaimana diamanatkan dalam Undangundang Keuangan Negara. Salah satu tujuan penerapan basis akrual yanga dalah menyediakan informasi yang lebih lengkap bagi pemerintah untuk pengambilan keputusan (Widjajarso, 2011). Dalam rangka implementasi akuntansi berbasis akrual, Pemerintah Pusat telah menyiapkan aplikasi SAIBA yang merupakan sistem akuntansi yang berbasi sakrual.

Penelitian ini mendukung teori Technology Acceptance Model (TAM) yang menyatakan bahwa kegunaan persepsian (perceived usefulness) dan kemudahan penggunaan persepsian (perceived ease of use) suatu sistem mempengaruhi pengguna untuk menerima dan menggunakan sistem tersebut. Kedua hal tersebut juga mendorong implementor untuk menerima dan menggunakan aplikasi SAIBA dengan memegang kepercayaan bahwa penggunaan aplikasi SAIBA tersebut memberikan kontribusi positif dalam implementasi akuntansi berbasis akrual. Selain kegunaan persepsian (perceived usefulness), tingkat pemahaman implementor terhadap akuntansi berbasis akrual akan mempermudah pengoperasian aplikasi SAIBA. Hal ini tentu saja akan membuat implementor lebih maksimal dalam menggunakan aplikasi SAIBA dalam penyusunan laporan keuangan berbasis akrual.

Hasil pengujian hipotesis melalui PLS menunjukkan bahwa nilai $t$-statistics $>$ t-tabel, yaitu 4,69 > 1,66. Hal ini menunjukkan bahwa penggunaan aplikasi SAIBA berpengaruh terhadap kualitas LKKL. Hasil penelitian ini mendukung teori Technology Acceptance Model yang dikembangkan Davis, et al. (1989). Hal ini menunjukan bahwa penggunaan aplikasi SAIBA akan membawa hal positif sehingga medorong pemerintah untuk menciptakan, menerapkan, dan menyempurnakan aplikasi SAIBA. Implementor yang memiliki persepsi yang sama akan mengambil sikap menerima penggunaan aplikasi SAIBA tersebut.

Kemajuan TI membantu pemerintah pusat merancang aplikasi SAIBA. Aplikasi SAIBA diharapkan dapat membantu penyelesaian LKKL dengan lebih mudah dan lebih cepat, dan meningkatkan tingkat akurasi data dan ketepatan informasi yang disajikan. Hal tersebut tentu saja menghasilkan informasi keuangan yang lebih berkualitas sebagai dasar pengambilankeputusan. Oleh karena itu, jika perusahaan tidak memiliki SIA yang baik akan mempengaruhi kemapuan perusahaan untuk menyediakan informasi yang baik guna pengambil keputusan yang tepat (McLeod dan Schell, 2001).

Hasil penelitian ini sejalan dengan penelitian penelitian Asterini (2015) yang menyatakan bahwa penggunaan teknologi informasi memiliki pengaruh terhadap kualitas laporan keuangan. Kemajuan teknologi informasi yang pesat serta potensi pemanfaatan secara luas maka dapat membuka peluang bagi berbagai pihak untuk mengakses, mengelola dan mendayagunakan informasi keuangan secara cepat dan akurat (Asterini, 2015). Hasil penelitian ini, tidak sejalan dengan penelitian Abas (2015) yang menyimpulkan bahwa penggunaan teknologi informasi tidak berpengaruh terhadap kualitas laporan keuangan.

Hasil pengujian hipotesis melalui PLS menunjukkan bahwa nilai $t$-statistics $>\mathrm{t}$-tabel, yaitu $4,45>1,66$. Hal ini menunjukkan bahwa implementasi akuntansi berbasis akrual berpengaruh terhadap kualitas LKKL. Hasil pengujian sejalan dengan hasil penelitian Ofoegbu dan Grace (2014) yang menemukan bahwa kualitas laporan keuangan akan meningkat secara signifikan dengan diimplementasikan nya akuntansi akrual dalam sektor publik. Penelitian Christanti (2013) juga menyimpulkan bahwa akuntansi berbasis akrual berpengaruh terhadap kualitas laporan keuangan.

Hasil penelitian ini yang menyatakan bahwa implementasi akuntasi berbasis akrual memiliki pengaruh dalam peningkatan kualias LKKL, akan mendukung decision usefulness theory. LKKL yang menyajikan informasi yang relevan, andal, dapat dibandingkan, dan dapat dipahami dapat menggambarkan posisi keuangan pemerintah dengan lebih tepat yang tentu saja dapat menjadi dasar pengambilan keputusan yang lebih baik. Meskipun implementasi akuntansi berbasis akrual dapat meningkatkan kualitas pengambilan keputusan baik bagi penyaji maupun pengguna laporan keuangan, namun penelitian ini lebih 
menekankan pada peningkatan kualitas LKKL dalam pengambilan keputusan oleh penyaji laporan keuangan itu sendiri.

Pergeseran dari akuntansi berbasis kas menjadi akuntansi berbasis akrual (di pemerintahan) untuk mendapatkan informasi keuangan yang bermanfaat (Simanjuntak 2005). Tujuan penerapan basis akrual adalah untuk meningkatkan kualitas pengambilan keputusan pemerintah (Widjajarso, 2011). Penggunaan basis akrual dalam pelaporan keuangan pemerintah, merupakan upaya untuk mendukung perbaikan kualitas laporan keuangan (Syaiful, 2014).

LRA merupakan komponen laporan keuangan yang menyediakan informasi mengenai realisasi pendapatan-LRA, belanja, transfer, surplus/defisitLRA, dan pembiayaan dari suatu entitas pelaporan yang masing-masing diperbandingkan dengan anggarannya. Informasi dalam LRA dapat digunakan sebagai umpan balik yaitu informasi berguna bagi penyaji laporan keungan dalam mengevaluasi keputusan mengenai alokasi sumber-sumber daya ekonomi dan mengevaluasi kinerja pemerintah dalam hal fisiensi dan efektivitas penggunaan anggaran. LRA juga memiliki manfaat prediktif dimana informasi yang disajikan di dalamnya berguna dalam memprediksi sumber daya ekonomi yang akan diterima untuk mendanai kegiatan pemerintah pusat dalam periode mendatang dengan cara menyajikan laporan secarakomparatif.

LO menyediakan informasi yang tidak diakomodir dalam LRA. LO menyajikan pendapatan LO, beban dan surplus defisit LO dan perbandingannya dengan periode sebelumnya. Nilai beban yang disajikan dapat digunakan untuk mengukur penilaian biaya suatu program/kegiatan yang lebih baik.

Laporan keuangan berbasis CTA belum memberikan rekam jejak atas perubahan nilai ekuitas pemerintah (Amriani, 2014). LPE menyediakan informasi mengenai perubahan ekuitas entitas pelaporan, apakah mengalami kenaikan atau penurunan sebagai akibat kegiatan yang dilakukan selama periode pelaporan. LPE disusun setiap bulan sehingga menyediakan informasi yang real time sebagai dasar pengambilan keputusan.

Angka yang disajikan dalam neraca juga menyajikan informasi yang lebih akurat. Pemisahan akun kas dan kas lainnya memperjelas penggunaan kas yang tersedia. Hal ini membantu meminimalisir risiko penyelewengan penggunaan kas. Penyajian utang dan piutang menunjukkan hak dan kewajiban pemerintah yang sebenarnya. Penyajian utang meningkatkan manajemen utang pemerintah yang dapat menghindarkan pemerintah dari risiko denda akibat utang yang jatuh tempo dan membantu pemerintah dalam melakukan rescheduling utang. Informasi piutang membantu pemerintah memprediksi dan mengalokasikan sumber daya yang akan diterima di masa mendatang. Depresiasi aset juga memberi peran dalam penyajian nilai aset tetap pemerintah yang lebih real. Akumulasi penyusutan membantu pemerintah untuk merencanakan pengadaan aset dengan belanja modal. Angka dari LPE yang menjadi input dalam neraca memberikan rekam jejak yang lebih baik atas nilai ekuitas dalam neraca.

Implementasi akuntansi berbasis akrual membawa perubahan baik dalam komponen laporan keuangan maupun informasi keuangan yang dihasilkan. Semakin baik implementasi akuntansi berbasis akrual, maka perubahan yang dihasilkan akan semakin meningkatkan kualitas LKKL sebagai dasar pengambilan keputusan. Besar harapan bahwa peningkatan kualitas LKKL di masa yang akan datang dapat disempurnakan dengan pencapaian opini WTP dari BPK.

Hasil pengujian Sobel menunjukkan bahwa nilai $t$-statistics >t-tabel, yaitu $3,88>1,66$. Hal ini menunjukkan bahwa implementasi akuntansi berbasis akrualberpengaruh terhadap kualitas LKKL dengan penggunaan aplikasi SAIBA sebagai variabel intervening. Hasil penelitian ini mendukung decision usefulness theory yang menyatakan bahwa informasi yang terkandung dalam laporan keuangan harus bermanfaat bagi para penggunanya sebagai dasar pengambilan keputusan. Implementasi akuntansi berbasis akrual diharapkan mampu menghasilkan LKKL berbasis akrual yang lebih berkualitas dan akuntabel. Pergeseran dari akuntansi berbasis kas menjadi akuntansi berbasis akrual untuk mendapatkan informasi keuangan yang bermanfaat (Simanjuntak, 2005). Penggunaan basis akrual dalam pelaporan keuangan pemerintah, merupakan upaya untuk mendukung perbaikan kualitas laporan keuangan (Syaiful, 2014).

Hasil penelitian ini juga mendukung Technology Acceptance Model yang dikembangkan Davis (1989). Implementasi akuntansi berbasis akrual untuk menghasilkan LKKL yang berkualitas dapat dicapai dengan penggunaan sistem informasi akuntansi yang mampu mengakomodir kebutuhan basis akrual. Menurut Jogiyanto (1995) informasi yang tepat waktu yang merupakan bagian dari nilai informasi dapat dicapai dengan peran komponen teknologi. Implementasi akuntansi berbasis akrual mendorong pemerintah memodifikasi aplikasi SAKPA yang selama ini digunakan dalam penyusunan laporan keuangan berbasis kas menuju akrual menjadi aplikasi SAIBA. 
Penggunaan aplikasi SAIBA dapat membantu implementasi akuntansi berbasis akrual untuk menghasilkan laporan keuangan yang berkualitas.

Pada aplikasi SAIBA, setiap transaksi yang telah direkam akan diproses ke dalam dua jurnal, yaitu jurnal kas dan jurnal akrual. Setelah proses penjurnalan selesai, tahap selanjutnya adalah proses posting ke buku besar kas dan buku besar akrual. Akun-akun Laporan Realisasi Aanggaran akan diposting ke buku besar kas, sedangkan akun-akun pendapatan dan beban akrualakan diposting ke buku besar akrual yang pada saat penyusunan laporan keuangan akan menghasilkan LO, LPE, dan neraca. Angka-angka yang ada di jurnal dan buku besar akrual adalah angka-angka yang berbasis kas dengan dokumen sumber SP2D. Oleh sebab itulah diperlukan penyesuaian untuk menentukan jumlah yang sebenarnya untuk setiap akun sesuai dengan basis akrual. Proses penyesuaian inilah yang mencerminkan sistem basis akrual.

Implementasi akuntansi berbasis akrual dengan penggunaan aplikasi SAIBA menyajikan informasi yang lebih komprehensif dan real time jika dibandingkan dengan basis kas menuju akrual yang digunakan sebelumnya. Output dari aplikasi SAIBA akan menghasilkan laporan keuangan yang lebih akuntabel dan berkualitas sebagai dasar pengambilan keputusan.

\section{SIMPULAN}

Berdasarkan pemaparan di atas, makadapat ditarik kesimpulan bahwaterdapat bukti adanya pengaruh implementasi akuntansi berbasis akrual terhadap penggunaan aplikasi SAIBA. Artinya, semakin baik implementasi akuntansi berbasis akrual, semakin mendorong penggunaan aplikasi SAIBA dalam penyusunanLKKL.Penelitian ini juga menemukan bukti adanya pengaruh penggunaan aplikasi SAIBA terhadap kualitas LKKL. Semakin maksimal penggunaan aplikasi SAIBA akan semakin meningkatkan kualitas LKKL yang disajikan. Aplikasi SAIBA akan menghasilkan output berupa beberapa komponen laporan keuangan yang lebih akurat, rinci, dan informatif yang akan meningkatkan kualitas informasi yang terkandung dalam LKKL tersebut.

Implementasi akuntansi berbasis akrual berpengaruh secara langsung terhadap kualitas LKKL. Hal ini disebabkan karena dengan basis akrual, informasi yang dihasilkan lebih komprehensif dan sesuai dengan kondisi yang sebenarnya, sehingga akan meningkatkan kualitas LKKL yang bermanfaat dalam pengambilan keputusan. Semakin baik implementasi akuntansi berbasis akrual, maka semakin meningkatkan kualitas LKKL.Pengujian Sobel dalam penelitian ini membuktikan bahwa penggunaan aplikasi SAIBA merupakan variabel intervening yang mempengaruhi hubungan antara implementasi akuntansi berbasis akrual terhadap kualitas LKKL. Artinya, semakin maksimal penggunaan aplikasi SAIBA dalam penyusunan LKKL berbasis akrual akan semakin meningkatkan kualitas LKKL yang dihasilkan.

Saran untuk peneliti berikutnya dapat mengembangkan variabel penelitian sesuai dengan model dasar teori TAM, yaitu persepsi kemudahan penggunaan aplikasi SAIBA. Teori TAM menyebutkan bahwa persepsi kemudahan penggunaan akan mempengaruhi niat menggunakan teknologi informasi (aplikasi SAIBA). Selain itu peneliti berikutnya dapat mengembangkan variable extronous yang mempengaruhi implementasi aplikasi SAIBA, seperti pelatihan pemanfaatan aplikasi SAIBA dan budaya organisasi.

\section{REFERENSI}

Abas, Haryon Y. (2015). Pengaruh Kualitas Sumber Daya Manusia dan Penggunaan Teknologi Informasi Terhadap Kualitas Laporan Keuangan Pemerintah Daerah (Studi Pada SKPD Se- Kota Gorontalo).

Amriani, Tenry Nur. (2014). Menyongsong Penerapan Akuntansi Pemerintah Berbasis Akrual.

Arianty, Erna. (2014). Peran Pemahaman Akuntansi Dasar Dalam Pengimplementasian Sistem Akuntansi Berbasis Akrual (SAIBA).

Asterini, Aina Purwa. (2015). Pengaruh Sistem Pengendalian Internal dan Pemanfaatan Teknologi Informasi Terhadap Kualitas Laporan Keuangan Pemerintah Daerah (Studi Kasus pada Satuan Kerja Perangkat Daerah Kota Bandung).

Ariesta, F. (2013). Pengaruh Kualitas Sumber Daya Manusia, Pemanfaatan Teknologi Informasi, dan Pengendalian Intern Akuntansi terhadap Nilai Informasi Pelaporan Keuangan Pemerintah Daerah (Studi pada Satuan Kerja Perangkat Daerah di Kabupaten Pasaman Barat). Skripsi. Universitas Negeri Padang.

Belkaoui, Ahmed Riahi. (2000). Teori Akuntansi. Salemba Empat. Jakarta.

Baron, R. M., \& Kenny, D.A. (1986). The Moderator-Mediator Variable Distinction in Social Psychological Research: Conceptual, Strategic, and Statistical Considerations. Journal 
of Personality and Social Psychology, 51(56), 1173-1182.

Christanti, Dianne Natalia. (2013). Pengaruh Akuntansi Berbasis Akrual dan Sistem Pengendalian Intern Terhadap Kualitas Laporan Keuangan. Tesis. UNIKOM.

Cooper, Donald R., \& C William Emory. (1997). Metode Penelitian Bisnis. Erlangga. Jakarta.

Davis, Fred. D. (1986). A Technology Acceptance Model For Empirically Testing New End-User Information Systems: Theory And Results. Desertasi Massachusetts Institute Of Technology. Ghozali, Imam, \& Hengky Latan. (2012). Partial Least Square, Konsep, Teknik dan Aplikasi SMARTPLS 2.0 M3 Untuk Penelitian Bisnis.Badan Penerbit UNDIP. Semarang.

Jogiyanto, HM. (1995). Analisis dan Desain Sistem Informasi \& Pendekatan Terstruktur Teori dan Praktek Aplikasi Bisnis. ANDI. Yogyakarta.

Lam, Nelson. dan Peter Lau. (2014). Akuntansi Keuangan : Perspektif IFRS. Salemba Empat. Jakarta

McLeod, R., \& Schell, G. P. (2001). Sistem Informasi Manajemen. Prenhallindo. Jakarta. PPAKP. 2014. Modul Overview Proses Bisnis SAIBA. Kemenkeu. Jakarta.

Muharor, Lalu Afgan. (2015). Studi Empiris Model Delone dan McLean dalam Kesuksesan KOMDANAS di Satuan Kerja Pengadilan. Tesis. Universitas Mataram.

Nasution, Fahmi Natigor. (2004). Penggunaan Teknologi Informasi Berdasarkan Aspek Perilaku (Behavioral Aspect).

Nengsy, Herda, Ria Nelly Sari, \& Restu Agusti. Pengaruh Partisipasi Penyusunan Anggaran terhadap Kinerja Manajerial dengan Job Relevant Information, Kepuasan Kerja, dan Motivasi sebagai Variabel Intervening. Jurnal Akuntansi, 2(1).

Ofoegbu., Grace N. (2014). New Public Management and Accrual Accounting Basis For Transparency and Accountability in the Nigerian Public Sector. IOSR-JBM, 16(7), 104-113.

Purba, Marisi P. (2010). International Financial Reporting Standards : Korvergensi dan Kendala Aplikasinya di Indonesia. Graha Ilmu. Yogyakarta.

Roni, Muhammad. (2015). Determinan Kualitas Laporan Keuangan Satuan Kerja di Wilayah Pembayaran Kantor Pelayanan Perbendaharaan Negara Mataram. Tesis. Universitas Mataram.

Sari, Dita Puspita., \& Hendrawan Santosa Putra. (2012). Menelisik Akuntansi Pemerintahan Berbasis Akrual. JEAM, 11(2), 33-56.

Simanjuntak, Binsar H . (2010). Penerapan Akuntansi Berbasis Akrual di Sektor Pemerintahan di Indonesia. Paper Kongres IAI ke-XI 9 Desember 2010.

(1989). Perceived Usefulness. Perceived of Use, and User Acceptance ofInformation Technology. MIS Quarterly, 13 (3), 319-340.

Simanjuntak, Binsar H. (2005). Menyongsong Era Baru Akuntansi Pemerintahan di Indonesia.

Scott, William R. 2003. Principal Accounting Theory. Prentice Hall. Canada.

Syaiful. (2014). Optimisme Kementerian/Lembaga Menyambut Penerapan Basis Akrual. Warta Pengawasan, 21(3), 44-47.

Switriansyah, Zulfirman. (2015). Pengaruh Kompetensi Aparatur, Pemanfaatan Teknologi Informasi, Time Pressure, dan Penerapan SAP Basis Akrual Terhadap Keandalan Informasi Laporan Keuangan. Tesis. Universitas Mataram.

Widjajarso, Bambang. (2011). Penerapan Basis Akrual pada Akuntansi Pemerintah Indonesia : Sebuah Kajian Pendahuluan.

Widoyoko, Eko Putro. (2014). Teknik Penyusunan Instrumen Penelitian. Pustaka Pelajar. Yogyakarta. 